This article was downloaded by: [TIB-Lizenzen - TIB Licence Affairs]

On: 30 April 2009

Access details: Access Details: [subscription number 777306419]

Publisher Taylor \& Francis

Informa Ltd Registered in England and Wales Registered Number: 1072954 Registered office: Mortimer House, 37-41 Mortimer Street, London W1T 3JH, UK

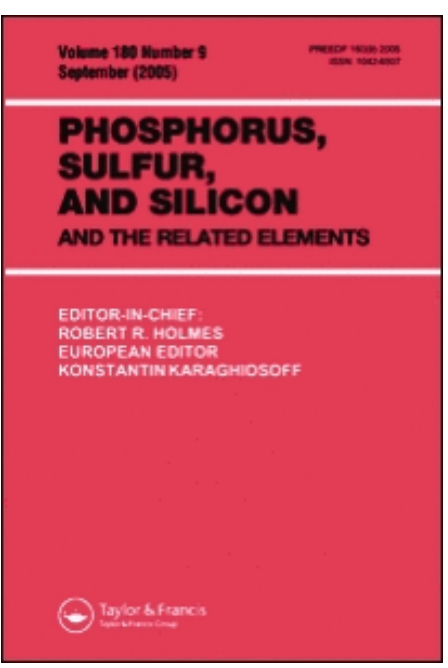

Phosphorus, Sulfur, and Silicon and the Related Elements

Publication details, including instructions for authors and subscription information: http://www.informaworld.com/smpp/title content=t713618290

\title{
Phosphorus-Boron and Phosphorus-Silicon Ring Systems Functionalization of Phosphorus Ring Systems
}

Bernhard Riegel a; Arno Pfitzner a; Gernot Heckmann a; Ekkehard Fluck a; Herbert Binder a

${ }^{a}$ Institut für Anorganische Chemie der Universität, Stuttgart

Online Publication Date: 01 August 1994

To cite this Article Riegel, Bernhard, Pfitzner, Arno, Heckmann, Gernot, Fluck, Ekkehard and Binder, Herbert(1994)'Phosphorus-Boron and Phosphorus-Silicon Ring Systems Functionalization of Phosphorus Ring Systems',Phosphorus, Sulfur, and Silicon and the Related Elements, $93: 1,173$ - 176

To link to this Article: DOI: $10.1080 / 10426509408021809$

URL: http://dx.doi.org/10.1080/10426509408021809

PLEASE SCROLL DOWN FOR ARTICLE

\footnotetext{
Full terms and conditions of use: http://www.informaworld.com/terms-and-conditions-of-access.pdf

This article may be used for research, teaching and private study purposes. Any substantial or systematic reproduction, re-distribution, re-selling, loan or sub-licensing, systematic supply or distribution in any form to anyone is expressly forbidden.

The publisher does not give any warranty express or implied or make any representation that the contents will be complete or accurate or up to date. The accuracy of any instructions, formulae and drug doses should be independently verified with primary sources. The publisher shall not be liable for any loss, actions, claims, proceedings, demand or costs or damages whatsoever or howsoever caused arising directly or indirectly in connection with or arising out of the use of this material.
} 


\title{
PHOSPHORUS-BORON AND PHOSPHORUS-SILICON RING SYSTEMS FUNCTIONALIZATION OF PHOSPHORUS RING SYSTEMS
}

\author{
BERNHARD RIEGEL, ARNO PFITZNER, GERNOT HECKMANN, \\ EKKEHARD FLUCK and HERBERT BINDER* \\ Institut für Anorganische Chemie der Universität, Pfaffenwaldring 55, \\ D-70569 Stuttgart
}

\begin{abstract}
The diphosphide $\mathrm{K}_{2}\left[(\mathrm{t}-\mathrm{Bu}) \mathrm{P}-\mathrm{BN}(\mathrm{i}-\mathrm{Pr})_{2}-\mathrm{P}(\mathrm{t}-\mathrm{Bu})\right]$ reacts with $\mathrm{t}-\mathrm{BuPCl}_{2}$ to form the $\mathrm{P}_{3} \mathrm{~B}$ ring system (i-Pr) ${ }_{2} \mathrm{NB}(\mathrm{t}-\mathrm{BuP})_{3} 1$. The five-membered $\mathrm{P}_{4} \mathrm{~B}$ ring system $(\mathrm{i}-\mathrm{Pr})_{2} \mathrm{NB}(\mathrm{t}-\mathrm{BuP})_{4} 2$ is formed from $\mathrm{K}_{2}\left[(\mathrm{t}-\mathrm{BuP})_{4}\right] 3$ and (i-Pr $)_{2} \mathrm{NBCl}_{2}$ analogous to the above reaction.

The reaction of 3 with $\mathrm{SiCl}_{4}$ or $\mathrm{Si}_{2} \mathrm{Cl}_{6}$ produces the novel five-membered ring systems (t-BuP $)_{4} \mathrm{SiCl}_{2} 4$ or $(\mathrm{t}-\mathrm{BuP})_{4} \mathrm{Si}(\mathrm{Cl}) \mathrm{SiCl}_{3} 5$ respectively.

New routes to the synthesis of the monofunctionalized cyclophosphanes $(\mathrm{t}-\mathrm{BuP})_{2} \mathrm{PCl} 6$ and $(\mathrm{t}-\mathrm{BuP})_{3} \mathrm{PCl} 7$ and to the new bifunctionalized cyclophosphane 1-Br-3-[(t-Bu)(Br)P]-2.4-(t-Bu $)_{2}-\mathrm{P}_{4} 8$ will be reported.

$1,2,4$, and 7 could be characterized by $X$-ray structure analysis; the structures of 5 and 8 could be inferred from NMR data. The ${ }^{31} P$ NMR spectra of 2 and 7 indicate $\left({ }^{10.11} \mathrm{~B}\right)$ and $\left({ }^{35.37} \mathrm{Cl}\right)$ isotopic shifts respectively.
\end{abstract}

\section{INTRODUCTION.}

Until recently, very few phosphorus boron ring compounds with P-P bonds were known, but a number of binary compounds have now been isolated where the basic unit appears to be a $P_{2}, P_{3}$, and $P_{4}$ fragment in the ring ${ }^{1-6}$. We have found that 1 and 2 are obtained by cyclocondensation reactions of the type $[1+3]$ or $[1+4]$ where ' 1 ' is a boron dihalide compound.

The reaction of 3 with functionalized silicon compounds provides a synthetic pathway to $\mathrm{P}_{4} \mathrm{Si}$ ring systems.

Functionalized cyclophosphanes were obtained by two different routes. Firstly, $[2+1]$ cyclocondensation reactions also take place when ' 1 ' is a dihalogenoamino phosphane thus leading to monoamino cyclotriphosphane. The amino group can readily be substituted by a chlorine atoin when reacted with $\mathrm{HCl}$. This variation circumvents the 
need for reactive silyl or stannyl substituted intermediates ${ }^{7}$. Secondly, in-situ generation of $[\mathrm{PX}](\mathrm{X}=\mathrm{Cl}, \mathrm{Br})$ from the system $\mathrm{PX}_{3} / \mathrm{SnX}_{2}{ }^{8}$ in the presence of $(\mathrm{t}-\mathrm{BuP})_{3}$ results in a ring expansion reaction thus forming a four-membered monohalogenated cyclotetraphosphane (t-BuP $)_{3} P X$. Depending on the reaction conditions a second phosphinidene $[\mathrm{PX}]$ is added exocyclic to a phosphorus atom of $(\mathrm{t}-\mathrm{BuP})_{3} \mathrm{PX}$ in $\beta$-position to $\mathrm{PX}$ simultaneously followed of a migration of that $\beta$-t-Bu group to the PX part.

\section{RJ SULTS AND DISCUSSION}

The new ring systems $\mathrm{P}_{3} \mathrm{~B}$ triphosphaboretane and $\mathrm{P}_{4} \mathrm{~B}$ tetraphosphaborolidine resulted from studies aimed at the generation of binary boron-phosphorus rings with P-P bonds. A $[3+1]$ cyclocondensation of $\mathrm{K}_{2}\left[(\mathrm{t}-\mathrm{Bu}) \mathrm{P}-\mathrm{BN}(\mathrm{i}-\mathrm{Pr})_{2}-\mathrm{P}(\mathrm{t}-\mathrm{Bu})\right]$ with $\mathrm{t}-\mathrm{BuPCl}_{2}$ give rise to produce the four-membered $\mathrm{P}_{3} \mathrm{~B}$ ring ${ }^{1}$

$$
\mathrm{K}_{2}\left[(\mathrm{t}-\mathrm{Bu}) \mathrm{P}-\mathrm{BN}(\mathrm{i}-\mathrm{Pr})_{2}-\mathrm{P}(\mathrm{t}-\mathrm{Bu})\right]+\mathrm{t}-\mathrm{BuPCl}_{2} \underset{-2 \mathrm{KCl}}{\longrightarrow}(\mathrm{i}-\mathrm{Pr})_{2} \mathrm{NB}(\mathrm{t}-\mathrm{BuP})_{3}
$$

$\mathrm{U}$ ing this route the $[4+1]$ cyclocondensation of $\mathrm{K}_{2}\left[(\mathrm{t}-\mathrm{BuP})_{4}\right]$ with $(\mathrm{i}-\mathrm{Pr})_{2} \mathrm{NBCl}_{2}$ yielded the five-membered $\mathrm{P}_{4} \mathrm{~B}$ ring system ${ }^{1}$.

$$
\mathrm{K}_{2}\left[(\mathrm{t}-\mathrm{BuP})_{4}\right]+(\mathrm{i}-\mathrm{Pr})_{2} \mathrm{NBCl}_{2} \underset{-2 \mathrm{KCl}}{\longrightarrow}(\mathrm{i}-\mathrm{Pr})_{2} \mathrm{NB}(\mathrm{t}-\mathrm{BuP})_{4}
$$

The molecular structure of $\mathbf{1}$ and $\mathbf{2}$ was determined from a single-crystal X-ray diffraction study, figure 1 and 2 .

The method described above can also be used for the synthesis of phosphorus-silicon rings. The five-membered $\mathrm{P}_{4} \mathrm{Si}$ ring was synthesized from 3 and $\mathrm{SiCl}_{4}$.

$$
\mathrm{K}_{2}\left[(\mathrm{t}-\mathrm{BuP})_{4}\right]+\mathrm{SiCl}_{4} \underset{-2 \mathrm{KCl}}{\longrightarrow}(\mathrm{t}-\mathrm{BuP})_{4} \mathrm{SiCl}_{2}
$$

Surprisingly, the two chlorine atoms of the $\mathrm{SiCl}_{2}$ group do not react with 3 to form the expected spiro compound; this kinetic inertness is due to the steric hindrance by the two 1-Bu groups. A X-ray crystal structure analysis of 4 is shown in figure 3 . The $\mathrm{P}_{4} \mathrm{Si}$ ring system is even formed when 3 is reacted with $\mathrm{Si}_{2} \mathrm{Cl}_{6}$. 


$$
\mathrm{K}_{2}\left[(\mathrm{t}-\mathrm{BuP})_{4}\right]+\mathrm{Si}_{2} \mathrm{Cl}_{6} \underset{-2 \mathrm{KCl}}{\longrightarrow}(\mathrm{t}-\mathrm{BuP})_{4} \mathrm{Si}(\mathrm{Cl})-\mathrm{SiCl}_{3}
$$

3

5

When irradiating 5 with u.v. light, compound 4 and $\left(\mathrm{SiCl}_{2}\right)_{\mathrm{n}}$ are produced and no disilene. The structure of 5 was proved by ${ }^{31} \mathrm{P}$ NMR and MS data; the ${ }^{31} \mathrm{P}$ NMR spectrum shows an AMRX spin system

We are particularly interested in the synthesis of functionalized cyclophosphanes. We have begun to explore the reactions of $\mathrm{K}_{2}\left[(\mathrm{t}-\mathrm{BuP})_{2}\right]$ with dihalogenoaminophosphanes in order to prepare new types of monofunctionalized cyclotriphosphanes. The replacement of the amino group by halogen atoms can easily be achieved with $\mathrm{HX}(\mathrm{X}=\mathrm{Cl}, \mathrm{Br})$.

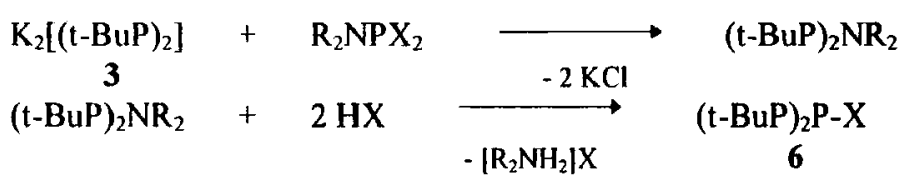

Furthermore, functionalization of cyclotetraphosphane was achieved by insertion of insitu generated phosphinidene $[\mathrm{PX}]$ into the $\mathrm{P}_{3}$ skeleton of cyclotriphosphane.

$$
(\mathrm{t}-\mathrm{BuP})_{3}+\mathrm{PX}_{3} / \mathrm{SnX} X_{2} \stackrel{[\mathrm{PX}] \text { addition }}{\longrightarrow} \quad\left[(\mathrm{t}-\mathrm{BuP})_{3}=\mathrm{P}-\mathrm{X}\right] \stackrel{[\mathrm{PX}] \text { insertion }}{\longrightarrow} \quad(\mathrm{SnCl}-\mathrm{BuP})_{3} \mathrm{P}-\mathrm{X}
$$

The multiplets of the ${ }^{31} \mathrm{P}$ NMR spectrum of 7 show satellites which are attributed to the ${ }^{35.37} \mathrm{Cl}$ isotopomers 7 was characterized by a X-ray structure analysis, Figure 4. Depending on the reaction conditions [PX] can even add to 7 , leading to an intermediate, which rearranges by migration of an $\alpha-\mathrm{t}-\mathrm{Bu}$ group to the exocyclic (=PX) group thus forming a bifunctionalized phosphino halogeno cyclotetraphosphane.

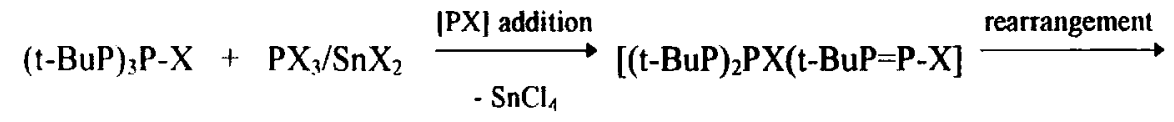

7

$$
1-X-3-[(t-B u)(X) P]-2.4-(t-B u)_{2}-P_{4}
$$

\section{8}

The ${ }^{31}$ P NMR spectrum of 8 corresponds to a ABMRX spin system. 


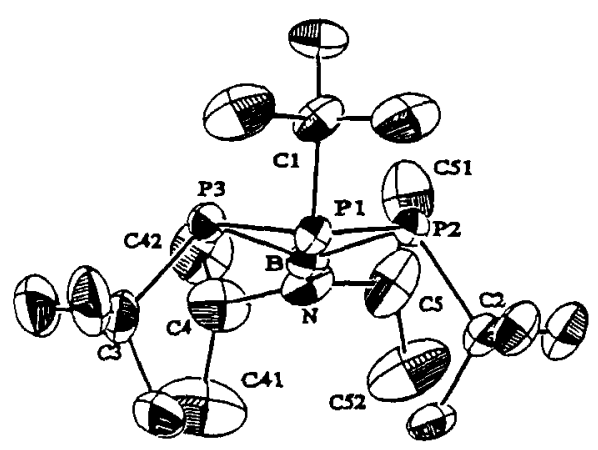

FIGURE 1 The Molecular Structure of $(\mathrm{i}-\mathrm{Pr})_{2} \mathrm{NB}(\mathrm{t}-\mathrm{BuP})_{3} \quad 1$

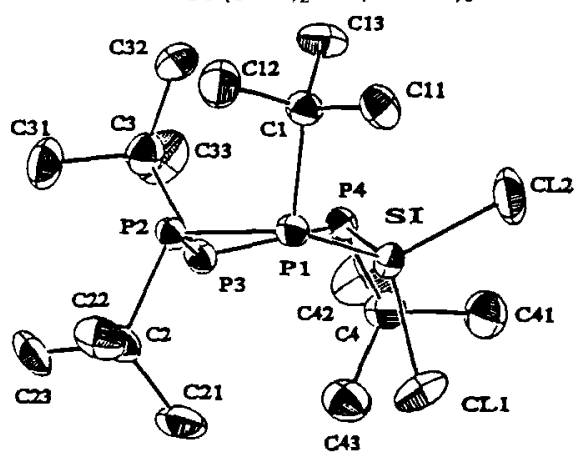

FIGURE 3 The Molecular Structure of $(\mathrm{t}-\mathrm{BuP})_{4} \mathrm{SiCl}_{2} 4$

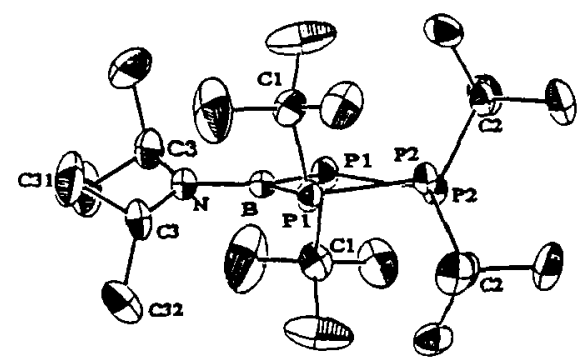

FIGURE 2 The Molecular Structure of (i-Pr) $)_{2} \mathrm{NB}(\mathrm{t}-\mathrm{BuP})_{4} 2$

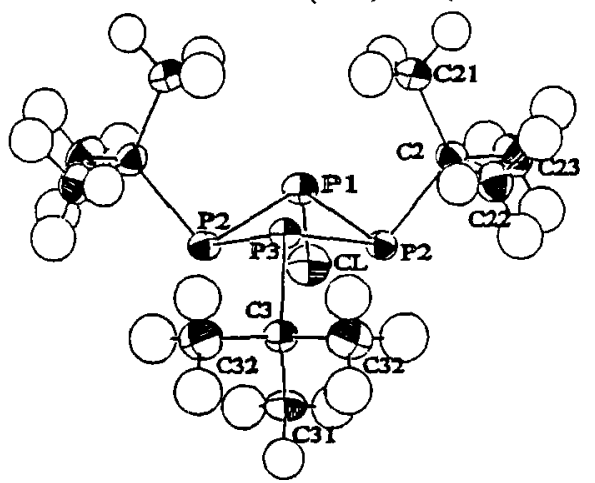

FIGURE 4 The Molecular Structure of $(\mathrm{t}-\mathrm{BuP})_{3} \mathrm{PCl} 7$

\section{REFERENCES}

1. B.Riegel, A.Pfitzner G.Heckmann, H.Binder, E.Fluck, Z. anorg.allg.Chem. 620 (1994) 8 .

2. M.Baudler, A.Marx, J.Hahn, Z.Naturforsch. 33b (1978) 355.

3. M.Baudler, M.Hintze, Z.anorg.allg.Chem. 522 (1985) 184.

4. M.Baudler, A.Marx, Z.anorg.allg.Chem. 474 (1981) 18.

5. P.Kölle, G.Linti, H.Nöth, K.Polborn, J.Organomet.Chem. 355 (1988) 7.

6. W.Haubold, W.Keller, G.Sawitzki, Angew.Chem. 100 (1988) 925; Angew.Chem. Int.Ed.Engl. 27 (1988) 925.

7. M.Baudler, B.Makowka, Z.anorg.allg.Chem. 528 (1985) 7.

8. A.Schmidpeter, S.Lochschmidt, W.S.Sheldrick, Angew.Chem. 94 (1982) 72; Angew.Chem. Int.Ed.Engl. 21 (1982) 63. 